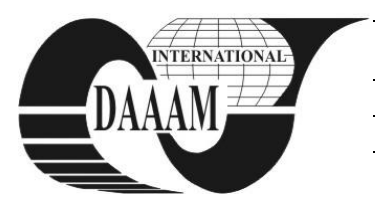

Annals of DAAAM for 2012 \& Proceedings of the 23rd International DAAAM Symposium, Volume 23, No.1, ISSN 2304-1382 ISBN 978-3-901509-91-9, CDROM version, Ed. B. Katalinic, Published by DAAAM International, Vienna, Austria, EU, 2012 Make Harmony between Technology and Nature, and Your Mind will Fly Free as a Bird Annals \& Proceedings of DAAAM International 2012

\title{
SANDWICH ABSORBERS AND THEIR ACOUSTIC PROPERTIES
}

\author{
BADIDA, M[iroslav]; BARTKO, L[adislav]; DZOGANOVA, Z[denka]; \\ KRALIKOVA, R[uzena] \& HRICOVA, B[eata]
}

\begin{abstract}
In spite of existing European and national legislation aimed at noise abatement, public interest and concern about noise are high. The EU Directive 70/157/EEC [15] for setting and controlling environmental noise is aimed at creating less noisy and more pleasant environment for European residents within "Sustainable Development in Europe". The authors are presenting a methodology for measuring selected acoustic descriptors (sound absorption coefficient and sound transmission loss) for acoustic materials, which are currently in process of development. Emphasis is put on sandwich structures of absorbers. Verification results of the proposed methodology are presented.

Keywords: environmental noise, noise wall, sound absorption coefficient, sound transmission loss, absorber, sandwich absorber
\end{abstract}

\section{INTRODUCTION}

In the European Union, about 80 million persons are exposed to high noise levels which are unacceptable or resulting disorders in sleep and other undesirable influences. There are approximately 170 million people living in the so-called "grey regions", where noise is very annoying.

Noise protection measures for reducing the effect of noise caused by transportation (road, railway and air transport) can be passive and active. [3], [4], [8]

Attention is paid to the design process and materials used for construction of noise walls and to their properties. The authors have focussed their attention on the research of new acoustic materials made on the basis of recycled materials and materials applicable for the structures of sandwich absorbers (two-layer and multiplelayer absorbers). [2], [6], [18]

The paper presents a proposed methodology for measuring selected acoustic descriptors (the sound absorption coefficient $\alpha$ and the sound transmission loss TL). [1]

\section{PROPORSAL OF METHODOLOGY FOR MEASURING SELECTED ACOUSTIC DESCRIPTORS OF ACOUSTIC MATERIALS, WHICH ARE CURRENTLY IN PROCESS OF DEVELOPMENT}

Authors have focused their attention on the two following descriptors:

- $\quad$ sound absorption coefficient $(\alpha)$,

- transmission loss (TL).
For measuring the sound absorption coefficient $(\alpha)$ and the transmission loss (TL) there are two theoretically available methods, namely: the method of standing wave ratio and the method of transfer function. The authors have used in their work the method of transfer function.

This method can be used for measuring the sound absorption coefficient, the reflection factor, the normal impedance and the normal admittance. The base of this method is the impedance tube (Fig. 1). [5], [16], [17]

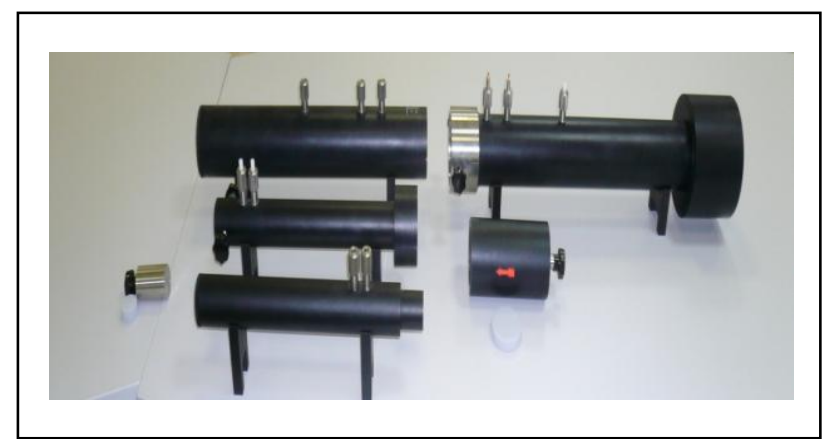

Fig. 1. The impedance tube

The proposed methodology of measurement includes the using of the impedance tube, two positions of positioning the microphones and the system of numerical frequency analysis for determining the sound absorption coefficient of sound absorbers for normal incidence of sound. Also it can be applied for determining acoustic surface impedance or acoustic surface admittance for sound absorbing materials, due to the fact that the impedance ratios of sound absorbing materials are proportional to their physical properties such as airflow resistance, porosity, elasticity and density.

This test method is similar to the test method specified in STN EN ISO 10534-1 [9] in terms of using an impedance tube with a sound source connected to one of its ends and a test specimen mounted into the tube at its other end. However, the actual test method is different. In this test method, the plane waves are generated in the tube by the sound source and the decomposition of the interference field is achieved by measuring acoustic pressures in two fixed positions of microphones mounted on the wall of the tube or by a microphone shifted in the tube and the subsequent calculation of the complex acoustic transfer function, by absorption at normal incidence and by impedance ratios of the acoustic material. This test method is designated to provide an alternative method of measurement, in general much faster than that included in STN EN ISO 10534-1[9]. 
The proposal of methodology for measuring selected acoustic descriptors by using an impedance tube and by applying the method of transfer function is presented in [1].

\section{VERIFICATION OF THE PROPOSED METHODOLOGY FOR MEASURING ACOUSTIC DESCRIPTORS FOR ACOUSTIC MATERIALS WHICH ARE CURRENTLY IN PROCESS OF DEVELOPMENT}

The proposed methodology of measurement was verified by measuring selected acoustic descriptors, namely: the sound absorption coefficient $(\alpha)$ and the transmission loss (TL) for the materials which are currently in process of development.

\subsection{Instruments, software and other equipment}

The system for measuring the sound absorption coefficient $(\alpha)$ (for the frequency bands of $100 \mathrm{~Hz}$ to 800 $\mathrm{Hz}$ and $400 \mathrm{~Hz}$ to $2500 \mathrm{~Hz}$, respectively) is discussed in [1]. It is comprised of a tube with inner diameter of 60

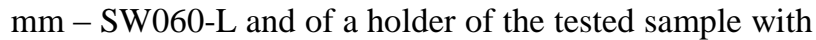
inner diameter of $60 \mathrm{~mm}$ - SW060-S. [10], [11], [13]

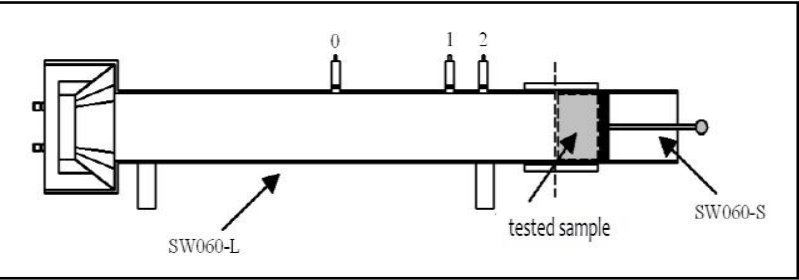

Fig. 2. The system for measuring the sound absorption coefficient (100 $\mathrm{Hz}$ to $800 \mathrm{~Hz}$ and $400 \mathrm{~Hz}$ to $2500 \mathrm{~Hz}$, respectively): 0,1,2 - mounting sockets for microphones

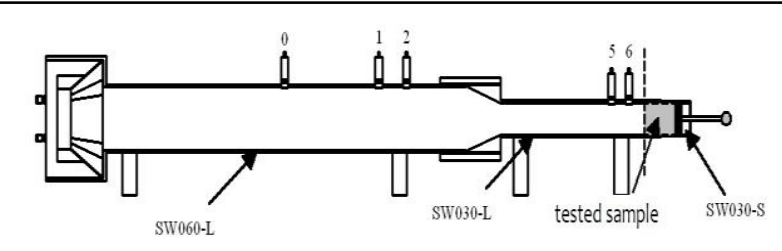

Fig. 3. The system for measuring the sound absorption coefficient (800 $\mathrm{Hz}$ to $6300 \mathrm{~Hz}$ ): 0,1,2,5,6-mounting sockets for microphones

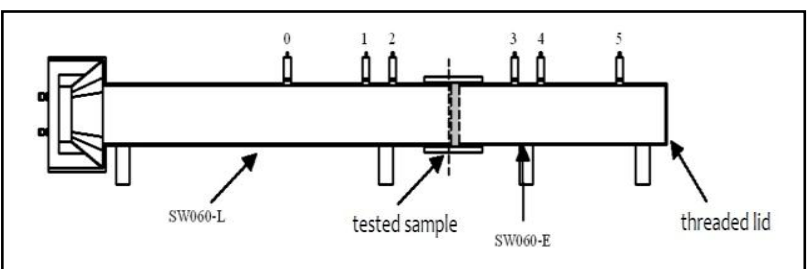

Fig. 4. The system for measuring the transmission loss TL $(100 \mathrm{~Hz}$ to $800 \mathrm{~Hz}$ and $400 \mathrm{~Hz}$ to $2500 \mathrm{~Hz}$, respectively): 0,1,2,3,4,5 - mounting sockets for microphones

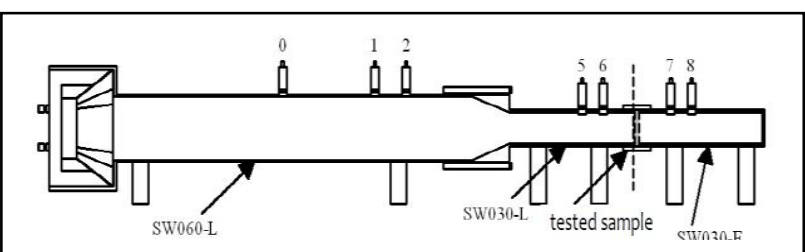

Fig. 5. The system for measuring the transmission loss TL $(1600 \mathrm{~Hz}$ to $6300 \mathrm{~Hz}$ ): 0,1,2,5,6,7,8 - mounting sockets for microphones
The system for measuring the sound absorption coefficient $(\alpha)$ (for the frequency bands of $800 \mathrm{~Hz}$ to $6300 \mathrm{~Hz}$ ) is discussed in [1]. It is comprised of a tube with inner diameter of $60 \mathrm{~mm}-\mathrm{SW} 060-\mathrm{L}$, of a tube with inner diameter of $30 \mathrm{~mm}-\mathrm{SW} 030-\mathrm{L}$ and of a holder of the tested sample with inner diameter of $30 \mathrm{~mm}-$ SW030-S. [10], [11], [14]

The system for measuring the transmission loss (TL) (for the frequency bands of $100 \mathrm{~Hz}$ to $800 \mathrm{~Hz}$ and $400 \mathrm{~Hz}$ to $2500 \mathrm{~Hz}$, respectively) is discussed in [1]. It is comprised of a tube with inner diameter of $60 \mathrm{~mm}-$ SW060-L and of an extension piece of the tube with inner diameter of $60 \mathrm{~mm}$ - SW060-E. [10], [11], [15]

The system for measuring the transmission loss (TL) (for the frequency bands of $1600 \mathrm{~Hz}$ to $6300 \mathrm{~Hz}$ ) is discussed in [1]. It is comprised of a tube with inner diameter of $60 \mathrm{~mm}-$ SW060-L, of a tube with inner diameter of $30 \mathrm{~mm}-\mathrm{SW} 030-\mathrm{L}$ and of an extension piece of the tube with inner diameter of $30 \mathrm{~mm}-$ SW030-E. [10], [11], [14]

\subsection{Selection of materials for the experimental part}

The selected acoustic descriptors (the sound absorption coefficient $\alpha$, the transmission loss TL) were measured for the following acoustic materials which are currently in process of development:

- Ekomolitan (Fig. 6) - is characterized by positiv thermal and sound insulation properties,

- Recycled rubber (Fig. 7) - is characterized by slip, watter permeable, vibroinsulation, reduces noise, reduces the fall, maintenance-free properties,

- Nobasil (Fig. 8) - it is amterial for thermal, sound and fire-fighting insulation of building construction and industrial equipment, in which the insulation is under compressive stress. [7]

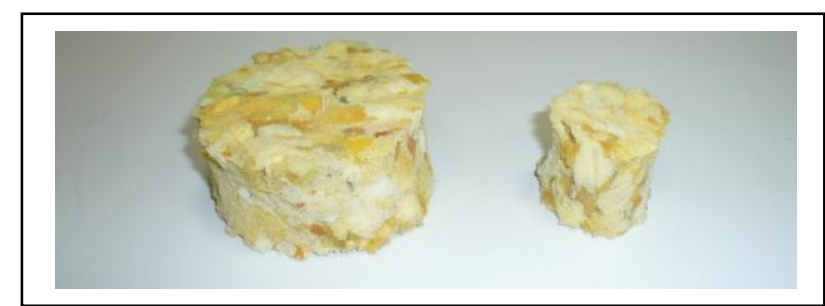

Fig. 6. Ekomolitan

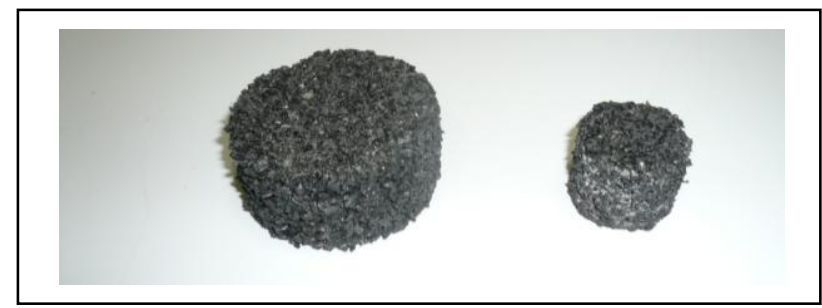

Fig. 7. Recycled rubber

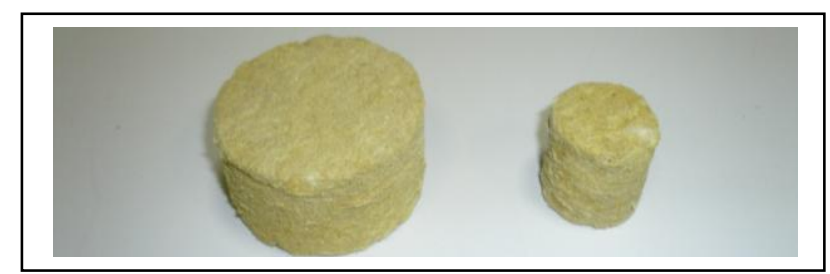

Fig. 8. Nobasil 


\subsection{Preparation of test samples}

The test samples of the three-layer sandwich absorbers were prepared in various combinations of materials such as Ekomolitan, Nobasil and recycled rubber. At the Fig. 9 a Fig. 10 are shown the combinations of mentioned materials.

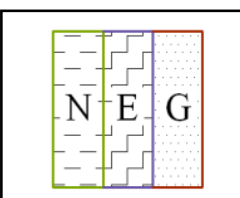

a)

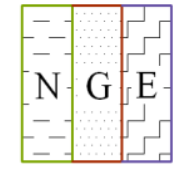

d)

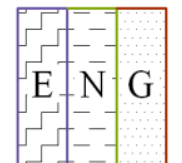

b)

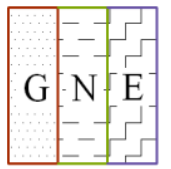

e)

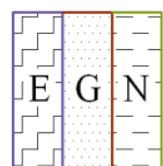

c)

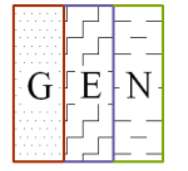

f)
Fig. 9. Three layer sandwich samples: N - Nobasil, G - recycled rubber, E - Ekomolitan

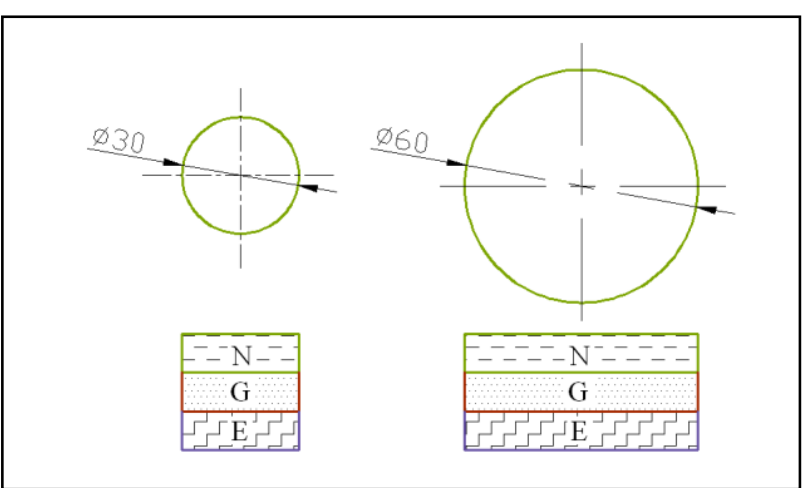

Fig. 10. Dimensions of three layer test sample

3.4 The measured values of the sound absorption coefficient and of the transmission loss

This part of the paper presents outputs from the measurement of the sound absorption coefficient carried out for a three-layer sandwich test sample composed of 2 $\mathrm{cm}$ thick Ekomolitan positioned closer to the sound source and of $2 \mathrm{~cm}$ thick Nobasil and of $2 \mathrm{~cm}$ thick recycled rubber positioned at end, as well as outputs from the measurement of transmission loss for a three-layer sandwich having the same material composition.

These outputs are given and explained in [1] whose evaluation is mentioned in conclusion of this contribution bellow.

\section{CONCLUSION}

The sound absorption coefficient $(\alpha)$ is a dimensionless number varying from 0 to 1 . The closer is the measured value to 1 or is equal to 1 , the sample of the measured absorber, and thus the absorber itself, will have a better (higher) sound absorption.

We have also measured the transmission loss (TL). It is a value in $\mathrm{dB}$ based on the ratio of the sound wave incident at the front side of the acoustically absorbing material to the sound waves transmitted from the rear side. TL represents the sound damping properties of the material, i.e. the higher that value is, and more efficient is the damping of the sound.
The authors have measured the coefficient of sound absorption $(\alpha)$ and the transmission loss (TL) for various combinations of three-layer sandwich absorbers composed of materials such as Ekomolitan, recycled rubber and Nobasil. Tab. 1 and Tab. 2 include the measured values of descriptors.

\begin{tabular}{|c|c|c|c|c|c|c|}
\hline \multirow[b]{2}{*}{ 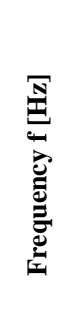 } & \multicolumn{6}{|c|}{ Sound absorption coefficient $\alpha[-]$} \\
\hline & 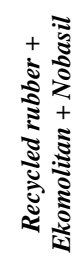 & 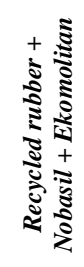 & 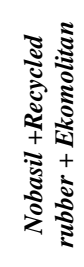 & 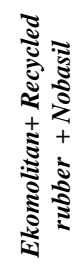 & 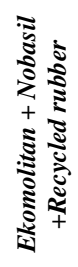 & 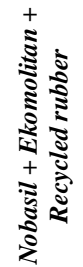 \\
\hline 500 & 0,786 & 0,622 & 0,469 & 0,716 & 0,624 & 0,505 \\
\hline 630 & 0,715 & 0,673 & 0,495 & 0,741 & 0,704 & 0,551 \\
\hline 800 & 0,609 & 0,649 & 0,479 & 0,693 & 0,777 & 0,567 \\
\hline 1000 & 0,515 & 0,612 & 0,506 & 0,672 & 0,841 & 0,648 \\
\hline 1250 & 0,445 & 0,549 & 0,625 & 0,689 & 0,872 & 0,628 \\
\hline 1600 & 0,381 & 0,472 & 0,718 & 0,779 & 0,931 & 0,564 \\
\hline
\end{tabular}

Tab. 1 The values of sound absorption coefficient of the materials with thickness of $6 \mathrm{~cm}$

\begin{tabular}{|c|c|c|c|c|c|c|}
\hline \multirow[b]{2}{*}{ 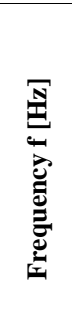 } & \multicolumn{6}{|c|}{ Transmission loss TL [dB] } \\
\hline & 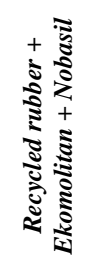 & 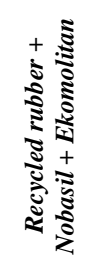 & 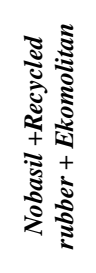 & 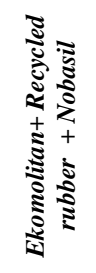 & 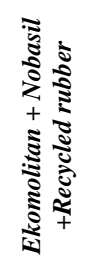 & 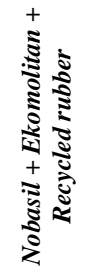 \\
\hline 500 & 15,845 & 14,816 & 15,324 & 15,086 & 14,744 & 15,375 \\
\hline 630 & 17,060 & 14,991 & 15,450 & 15,642 & 14,825 & 16,075 \\
\hline 800 & 19,336 & 16,151 & 16,526 & 16,893 & 15,901 & 17,932 \\
\hline 1000 & 21,458 & 18,201 & 18,101 & 16,220 & 16,931 & 17,652 \\
\hline 1250 & 21,515 & 16,690 & 15,048 & 17,916 & 18,142 & 21,949 \\
\hline 1600 & 25,195 & 21,604 & 20,000 & 20,140 & 21,307 & 24,455 \\
\hline
\end{tabular}

Tab. 2 The values of transmission loss of the materials with thickness of $6 \mathrm{~cm}$

The frequency spectrum of noise caused by transportation reaches its maximum in the frequency range of $500 \mathrm{~Hz}$ to $1500 \mathrm{~Hz}$, and the most intensive noise is caused at the frequency of $1000 \mathrm{~Hz}$.

Noise walls (barriers) are often constructed as noise panels with supporting frame using sandwich absorbers. For the purpose of the thesis, samples representing a sandwich composed of materials such as recycled rubber, Nobasil and Ekomolitan were made. The arrangement of individual layers of the sandwich was different. Measurements have been carried out for three-layer sandwiches (Fig. 11 and Fig. 12). 


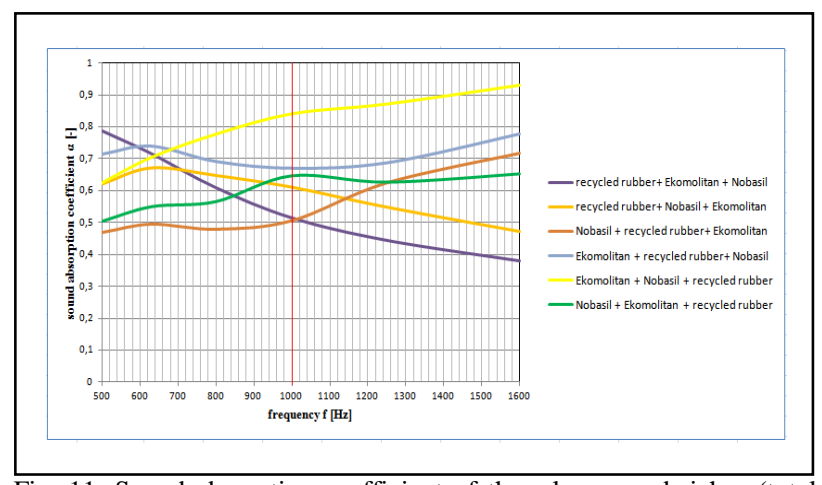

Fig. 11. Sound absorption coefficient of three-layer sandwiches (total thickness of the sandwiches: $6 \mathrm{~cm}$ )

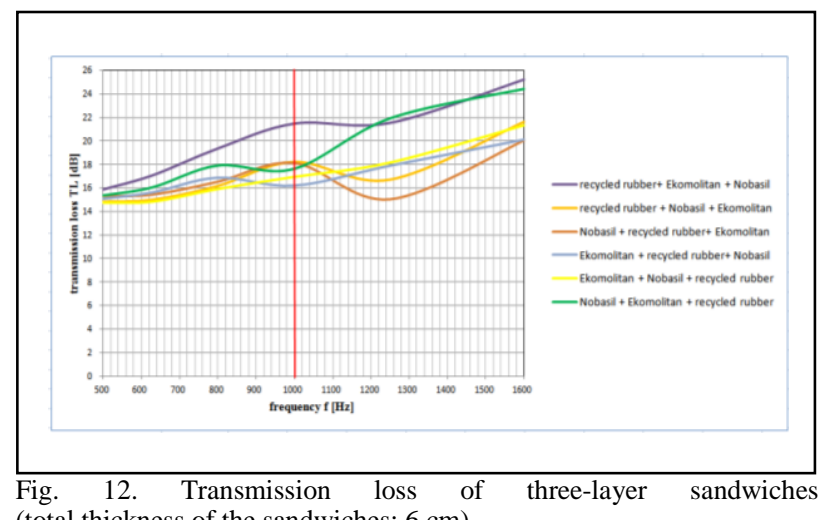

(total thickness of the sandwiches: $6 \mathrm{~cm}$ )

From the measured values of the sound absorption coefficient of the sandwich absorbers follows that the sequence of individual layers (of utilized materials) is of crucial importance.

The sequence of the sandwich layers of the measured materials, starting from the noise source (for the frequency of $1000 \mathrm{~Hz}$ ), is recommended as follows:

- Ekomolitan + Nobasil + recycled rubber.

It can be stated on the basis of the measured values of transmission loss of the sandwich absorbers (Fig. 7) that the sequence of individual layers of materials utilized in the sandwich is also of crucial importance.

The sequence of the sandwich layers of the measured materials utilized for three-layer sandwiches, starting from the noise source, is recommended as follows:

- Recycled rubber + Ekomolitan + Nobasil.

The next step will be focused on measurement carried out environment $\mathrm{v}$ period half year to find out the changes properiet of these sandwich absorbers.

\section{ACKNOWLEDGEMENTS}

This contribution was worked - out frame within the frame project KEGA No 049TUKE-4/2012.

\section{REFERENCES}

[1] Badida, M.; Lumnitzer, E. \& Bartko, L.: Možnosti znižovania dopravného hluku. Košice: Elfa, 2011. 303 s. ISBN 978-80-8086181-0

[2] Matel, F. - Ochocová, R. - Badida, M. - Lumnitzer, E. Kompaktné prvky $z$ gumárenského recyklátu vyrobené technológiou mikrovlnného ohrevu. Úrad Priemyselného Vlastníctva SR, Banská Bystrica, 2003

[3] Badida, M. - Lumnitzer, E. - Fil'o, M. - Bil'ová, M. Determination of the uncertainties of noise measurements. In: Annals of the Oradea University: Faculty of management and technological engineering. Vol. 7, 2008. p. 64-72. ISSN $1583-$ 0691

[4] Bartko, L. - Vargová, J.: Zásady navrhovania a materiály vhodné pre konštrukciu protihlukových stien. In: Ekológia a environmentalistika: zborník príspevkov doktorandov zo 7 . Študentskej vedeckej konferencie: 24. mája 2010, Zvolen. Zvolen: TU, 2010. s. 21-27. ISBN 978-80-228-2111-7

[5] Bartko, L. - Vargová, J.: Analýza prístupov ku konštrukčnému a materiálovému riešeniu protihlukových stien. In: Ochrana životného prostredia pred hlukom : zborník $\mathrm{z}$ odborného seminára: Hodnotenie kvality prostredia 2010 : zborník z konferencie : 1. ročník odborného seminára a konferencie $s$ medzinárodnou účast'ou : zborník príspevkov : 22.-23. september 2010, Košice. Košice : TU, SjF, 2010. s. 138-143. ISBN 978-80553-0489-2

[6] Lumnitzer, E. - Badida, M. - Liptai, P.: Využitie recyklantov z autovrakov pri návrhu protihlukových opatrení v lomoch. In: TOP 2010: technika ochrany prostredia, 15-17.jún 2010, Častá Papiernička, Bratislava. s. 251-256. ISBN 978-80-970438-0-3

[7] Badida, M. - Lumnitzer, E. - Romanová M.: The application of recycled materials for products that provide noise reduction in living and working environment. In: Acta Acoustica United with Acoustic. Vol. 92. Stuttgart: Hirzel Verlag, 2006. p. 108. ISSN 1610-1928

[8] Neugergerová, K.: Ekologické aspekty dopravy. Praha: ČVUT, 2005. 163 s. ISBN 80-01-003131-4

[9] STN EN ISO 10534-1: 1996, Akustika. Určovanie koeficienta zvukovej pohltivosti a akustickej impedancie v impedančných trubiciach. Čast' 1: Metóda použitia stojatej vlny

[10] STN EN ISO 10534-2: 1998, Akustika. Určovanie koeficienta zvukovej pohltivosti a akustickej impedancie $\mathrm{v}$ impedančných trubiciach. Cast' 2: Metóda transformačnej funkcie

[11] STN ISO 10847: 2000, Akustika. Stanovenie vložného útlmu vonkajších protihlukových bariér všetkých typov na mieste trvalého uloženia (in situ)

[12] STN EN 1793-1: 1997, Zariadenia na zníženie hluku z cestnej dopravy. Skúšobné metódy určovania akustických vlastností. Čast' 1: Určenie zvukovej pohltivosti

[13] STN EN 1793-2: 1997, Zariadenia na zníženie hluku z cestnej dopravy. Skúšobné metódy určovania akustických vlastností. Čast' 2: Určenie vzduchovej nepriezvučnosti

[14] STN EN 1793-3: 1997, Zariadenia na zníženie hluku z cestnej dopravy. Skúšobné metódy určovania akustických vlastností. Cast' 3: Normalizované spektrum dopravného hluku

[15] Nariadenie vlády SR č. 115/2006 Z. Z., o minimálnych zdravotných a bezpečnostných požiadavkách na ochranu zamestnancov pred rizikami súvisiacimi s expozíciou hluku

[16] Nariadenie vlády SR č. 339/2006 Z. z., ktorým sa ustanovujú podrobnosti o prípustných hodnotách hluku, infrazvuku a vibrácií a o požiadavkách na objektivizáciu hluku, infrazvuku a vibrácií

[17] Smernica Rady EÚ zo 6. februára 1970 o aproximácii právnych predpisov členských štátov o prípustnej hladine hluku a o výfukových systémoch motorových vozidiel. [online] [cit 201011-21]. Dostupné na internete: <http://eurlex.europa.eu/LexUriServ/LexUriServ.do?uri=CELEX:31970L01 57:sk:NOT>

[18] Ministerstvo dopravy, pôšt a telekomunikácií SR. Použitie, kvalita a systém hodnotenia protihlukových stien. Účinnost' od: 01-122006. [online] [cit 2011-02-01]. Dostupné na internete: http://www.telecom.gov.sk/files/doprava/dopinfra/cesinfra/tech_p redpisy/2006/tp_08_2006_.pdf 